\title{
THE POPULAR NOBEL PRIZE AWARD BANQUET: DISTANCED PARTICIPATION OF AN INTERACTING TV-AUDIENCE
}

\author{
Marlene Hugoson
}

\begin{abstract}
When chemist, inventor, and businessman Alfred Nobel died in 1896 he left a will establishing the Nobel Prize. Over the years, the Nobel Prize Award Ceremony, and the following Nobel Prize Award Banquet, developed into a spectacular and well-known event that was sometimes broadcast on radio. Then, in the year 1950, it was shown on Swedish television for the first time. In the decades that followed television became part of almost each and every household, and the viewing audience could now follow the festivities as they occurred, almost as if they had been invited themselves. A playful attitude towards the event developed, consisting of banter but also of distanced participation in which people dressed up and staged their own Nobel Prize Award "banquets" in front of their televisionsets. In later years this phenomenon has developed, simultaneously becoming both more elaborate and more common, and today there is a variety of privately arranged Nobel Prize Award "banquets" to be found throughout Sweden, some even including their own Nobel Prize Award Ceremonies and attending royalty. In my paper, I will present this public parallel to the highly exclusive Nobel Prize Award Banquet and touch on international counterparts to it and the humorous language that surrounds these events.
\end{abstract}

Key words: Alfred Nobel, annual festivity, banter, dressing up, national pride, Nobel Prize Banquet, parody, role play

On the eve of December 10, a Swedish couple would sit down to enjoy their dinner while watching the Nobel festivities on television. TV-dinners are ordinarily frowned upon, but on this night it is considered part of the celebration of Alfred Nobel, but there are also more elaborate celebrations to be found, where family and friends are invited to a fancy celebratory meal - many times with the TV present and turned on. Sometimes there is a mix of participants attending this fancy dinner, and at other times the "Nobel Banquet" is for couples only (including homosexual couples), or it is the theme of a girls' night (ULMA 39316, 39319-39322: 1). ${ }^{1}$

These alternative Nobel Banquets represent a new and developing annual festivity in Sweden, and they are often held at the same time as the real Nobel 
Prize Award Banquet takes place in Stockholm, on the eve of December 10 each year. In my paper - previously presented at the SIEF conference The Ritual Year and Ritual Diversity. Second Conference of the SIEF Working Group on the Ritual Year ${ }^{2}$ in Gothenburg 2006 - I will examine this public parallel to the highly exclusive Nobel Prize Award Banquet, and touch on historic and international counterparts to it, and the banter and role-play that surrounds this. ${ }^{3}$

\section{THE NOBEL PRIZE}

Before his death in 1896, chemist, inventor, and businessman Alfred Nobel left instructions in his will for the Nobel Prize. Five years later the Nobel Foundation was created to recognise advances in physics, chemistry, physiology or medicine, literature and peace. Later, in 1969, the Nobel Prize in Economy was established in Alfred Nobel's honour. ${ }^{4}$

Over the years, the Nobel Prize Award Ceremony, and the ensuing Nobel Prize Award Banquet developed into a grand and well-known event that in parts was broadcast over the radio. Then, in the year 1950, it was shown on Swedish television for the first time. The event was among the first to be featured on television, which may have contributed to the special status it came to secure in the public mind (SVT production 2004; http://www.ur.se/television).

In the decades that followed, a television set became part of almost each and every household, and the viewing audience could now follow the festivities as they occurred, almost as if they had been invited themselves. The broadcasts even continued throughout the revolutionary era of the 1960s when class society was largely deconstructed in Sweden. Over time a playful attitude towards the event began to develop, consisting of banter but also of distanced participation during which people dressed up and staged their own Nobel Prize Award Banquets in front of their own television sets.

In later years, this phenomenon has evolved further, simultaneously becoming both more elaborate and more common, and today there is a variety of privately arranged Nobel Prize Award "Banquets" to be found throughout Sweden (ULMA 39316-39322).

\section{ALTERNATIVE NOBEL PRIZE AWARD BANQUETS}

Alternative Nobel Banquets are not only held in private homes; various organisations may also arrange their own celebration, such as local folklore societies, where the members take turn in arranging the banquet and dress up in white 
tie or the folk costume of that area, and also organisations like the Scouts, United Nations Stockholm, Rotary International, the Order of Good Templars, the Swedish Temperance Organisation, and finally prominent Swedish politicians who were not invited to the real thing (ULMA 39322: 3).

The Nobel Banquets staged at the Swedish residence in New York are semiauthentic - the guests include former laureates, as in the case of "The Small Nobel Prize Banquet" arranged by the Nobel Museum for children within the age of 7 to 11 (ULMA 39322: 3).

The students at some of the Swedish colleges and universities also want to partake in the celebration by staging their own Nobel Banquets, for example in the cities of Borås, Umeå and Uppsala (ULMA 39322: 2). In Umeå, the issue of homosexuality raised some questions, as gay couples were welcome to attend the banquet, but were not allowed to sit together, because of the high level of etiquette demanded in the seating arrangements: lady-gentleman, ladygentleman (Kinberg 1999). According to strict etiquette, couples are generally not allowed to sit together anyway as during the Nobel Banquet, for example, the Swedish Queen does not sit next to the King. However, the problem is accentuated when there is an unbalance in the number of men and women attending, as outlined in the example above.

Commercial interests have also picked up on the growing popularity of the Nobel Banquets, as the more exclusive caterers, restaurants, hotels and inns have begun to serve Nobel Banquets in the same price range as the real banquet. Furthermore, professional business operators are organising private tours of the Nobel Museum followed by a Nobel Banquet at Stockholm City Hall - i.e. where the real Nobel Banquet is held (ULMA 39322: 4).

\section{PRACTICE MAKES PERFECT}

What is more interesting is that school kitchens have begun to serve a Nobel Prize Banquet for lunch at both kindergartens and schools. This two or threecourse meal is often based on the menu of the previous year's real Nobel Banquet, but is priced at around 10 Swedish kronor - compared to the approximately 1,400 kronor ticket to the real Nobel festivities, which was the charge in 2005 (ULMA 39316-39318, 39322: 2).

Some schools have embraced the idea and developed it further by arranging workshops and their own evening banquets, with fancy dresses and dancing. In the workshops, the students learn about manners and etiquette, or inventions, or they may research the Peace Prize laureates and make presentations using 
role-play. There are also examples of classes with disabled students organising celebratory Nobel Banquets (ULMA 39322: 2).

For many of the younger boys the banquet is a rare, and sometimes a first, occasion to wear a tie. And for the girls a first real occasion to wear a ball gown, high heels and a tiara, as opposed to playing a princess at home. The evening may thus serve a socialising purpose, giving the children a cultural lesson in etiquette, dancing, manners, and to some extent, work, as students sometimes learn to set and decorate a table, and to prepare the food. The younger students at some schools also help serve the food to the older students. Again examples of the TV's presence at the banquet can be found (ULMA 39322: 2).

As the real Nobel Banquet is sometimes held during the weekend, the schools occasionally move their celebration to a previous or later evening that works better with the school schedule (ULMA 39317-39318, 39322: 2). This is sometimes also the case with the Nobel Banquets held in the homes, where the celebration is sometimes shifted to New Year's Eve (ULMA 39316).

\section{RECIPE FOR A NOBEL PRIZE AWARD BANQUET}

The ambition level and concept of these privately arranged Nobel Banquets run from basic simplicity to an elaborate festivity throughout, ranging from an ordinary dinner in front of the TV to the whole shebang, with formal invitations specifying the dress code, to fancy food, dancing, and even "Hobnobbing in The Blue Hall" - a reference to the Blue Hall of Stockholm City Hall, which is especially amusing if you actually happen to have a blue coloured hallway, even though the Blue Hall of Stockholm City Hall paradoxically is not blue (ULMA 39316-39322).

The banquet food served at these private gatherings may thus run from the ordinary to the exclusive, sometimes inspired by one of the many books or cookbooks on the Nobel Banquet. ${ }^{5}$ Even the table decorations may be copied, as the china and crystal and silver- and gold-ware, from well renowned Swedish artists and manufacturers, is available to the public in the better-stocked shops (ULMA 39316-39322).

In recent years, the Swedish daily newspapers have begun to run articles on the topic of "How to Create Your Own Nobel Banquet" and in the days leading up to the Nobel Award Ceremony and the Nobel Banquet, examples of menus are printed along with tips on where to go for the night, at low cost, dress, hairdo and food (ULMA 39322: 1). One such tip suggested going to a Syrian shop for the dress: an example of how a foreign culture in Sweden may suddenly receive unexpected yet positive attention in an otherwise unlikely context (Forsström 


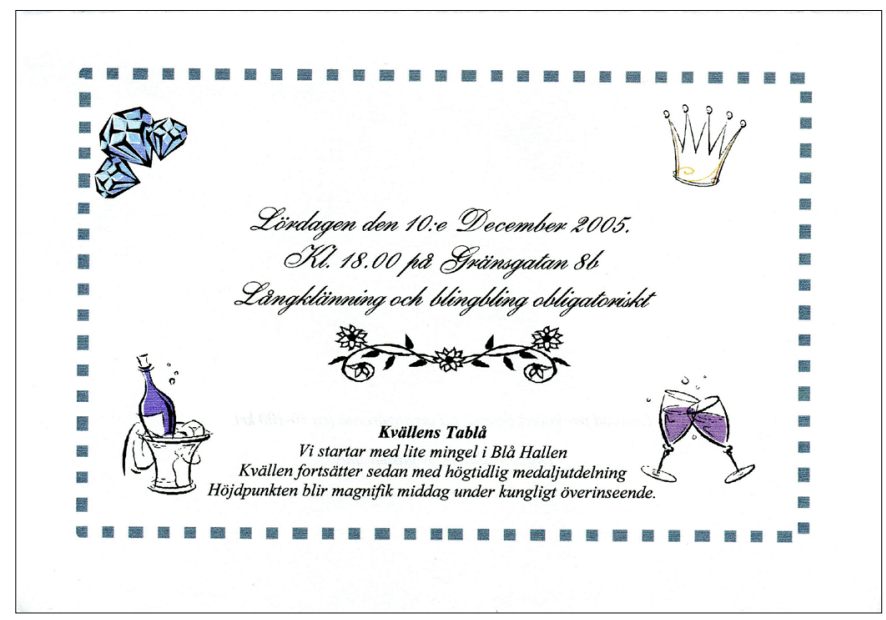

Figure 1. Invitation to a private Nobel Banquet, reading: "Evening gown and bling bling obligatory (...). We will kick off with some hobnobbing in the Blue Hall. The evening will then continue with a grand award ceremony. To top things off, a magnificent dinner under Royal supervision"

i.e. through the media of television. () The Swedish Institute for Language and Folklore

2005). It should be noted that I have found no account of immigrants organising Nobel Banquets; however, this may change as immigrant children participate in the Nobel activities at school, and may want to bring the celebration into their home as well (ULMA 39317, 39322).

Aside from food, the attire plays a major part in the private celebration. Although young Swedes are known for their fashion sense, Swedes in general are not known to be well dressed, rather for wearing more functional clothes. The Nobel Banquet, however, is a rare occasion to put on a show, mimicking the glamour and dress code of the real Nobel Prize Banquet down to the jewellery: often fake tiaras bought at the toy store, and also sashes, rosettes, and medals (ULMA 39319-39322).

Gender is a factor in this context, since it is mainly females who take the initiative to stage these private banquets, maybe because of a "Cinderellasyndrome/complex" where they, if only for a night, get to attend the proverbial ball (ULMA 39316-39322). 


\section{ROLE PLAY AND BANTER}

At the private Nobel Banquets spirits are high and the mood is playful, as people get a kick out of the formal etiquette and the dressing-up. At the same time, the banter surrounding the Nobel festivities is often scented with parody, making fun of class and belonging - as both of these are perceived to be old fashioned notions in today's more democratic Swedish society. Also, any jokes consisting of the word dynamite or referring to explosions are appropriate, as Alfred Nobel was the man who invented this explosive substance, for instance: "The Nobel Prize Award was dynamite this year!"

There are various forms of role-play: children acting more like adults and adults mimicking the higher classes (ULMA 39319-39322). This is especially apparent when the humorous banter is delivered with a simultaneous change in speech pattern, thus impersonating someone from a higher social stratum: "It is so strange, I did not get an invitation this year." Or: "No, I was not nominated this year either, so I didn't bother to go." If preparations are still needed in the kitchen, an excuse can also be made in the form of an explanation that is again a social comment regarding class: "Well, you see the kitchen maid is off this evening, so I have to manage on my own." In reality, of course, there is no maid (ULMA 39319-39321).

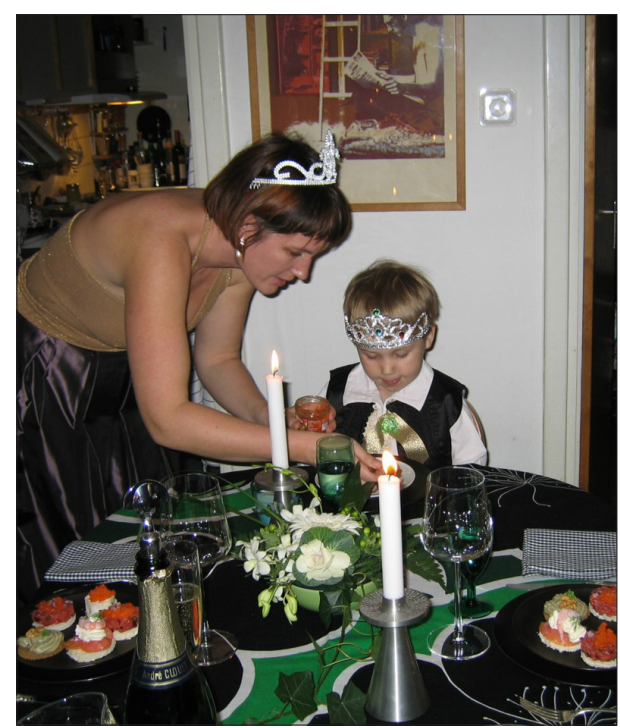

Figure 2. "Nobel Prize Award Banquet" served in a private home in Umeå, Sweden 2004. Photo: Marlene Hugoson. (C) The Swedish Institute for Language and Folklore 
There are also examples of people dressing up and acting the parts of King and Queen, the Crown Princess, or Alfred Nobel himself at these banquets. ${ }^{6}$ In one instance, a hand puppet placed on Queen Silvia's hand was used to represent King Carl XVI Gustaf - yet another example of the humour. These celebrities lend glamour to the evening and present Nobel medallions and diplomas to the "laureates". These prizes are often hand-made or in the shape of a gold-covered chocolate medallion similar to the kind served at the real Nobel Banquet and sold by the Nobel Museum in Stockholm (ULMA 39322: 2-3). ${ }^{7}$

The nominations for the prize are tailored to suit the "laureates". For example, an unspecified Nobel Prize can be given by a countryside folklore society for efforts developing that specific area. A Nobel Prize in chemistry can be given for excellence in the kitchen, and in physics for excellence when handling a vacuum cleaner. Some schools award prizes for academic excellence to all of the best students, and at one school Peace prizes were also given to students who had proved themselves to be good classmates (ULMA 39321, 39322: 2).

\section{HISTORIC COUNTERPARTS AND DEMOCRATIC ASPECTS}

Class snobbery and social division are still all firmly in place, but tempered by the possibility of Everyman gaining admittance. (Strong 2002: 308)

A historic parallel to the TV audience, watching the royals eat during the televised Nobel Banquet, is found in the Renaissance Banquet, and the sixteenth to eighteenth century custom of popes and royalty dining in public; admission to the table was limited and the guests or spectators only had the honour of watching the Pope or royals eat and did not partake themselves (Strong 2002: 134, 202-258). ${ }^{8}$ This effect is achieved now through the medium of television: the present-day television viewer takes on the part of a guest at one of these public banquets.

In today's televised broadcasts, from the Nobel Banquets, the royals set a higher standard to which many viewers would like to strive, in both decorum and appearance. The idea of bettering oneself is also promoted in the televised broadcasts where prominent Swedish authorities on etiquette, such as author Magdalena Ribbing, are called in to explain the "rules" of the occasion, thus giving the viewers a lesson in etiquette (SVT 2005). This knowledge lends a feeling of equality and belonging, while simultaneously marking the difference in class and education between the viewer and the attending guests. 
It is interesting to note that the Nobel Banquet is a rare example of an instance when the Law of Jante is largely set aside. The Law of Jante is a term used to describe the Scandinavian parochial mentality, in which jealousy and striving for equality allows people to mock those who consider themselves above others, and never lets anyone else feel good about their achievements. ${ }^{9}$ During the Nobel Banquet, however, the previously mentioned banter with class and belonging has its limits, showing a boundary for this law; when a provocative author and feminist columnist for one of the two largest evening newspapers in Sweden was sent to cover the Nobel Banquet in 2004, the columnist provoked the other guests at her table, and the viewers at home, by vulgar speech and a total disregard for the "rules" of the occasion. To top things off she gave the Nobel Banquet a very distasteful review in the paper the following day (SVT 2004; ULMA 39316; Skugge 2004a). All of this proved to be a faux pas and a public reaction to her display of bad manners followed (Karlsson 2004; Skugge 2004b).

The Nobel Prize is a matter of national pride for many Swedes, and eager viewers wanted to see and hear only of the glamour and therefore disliked the fact that the columnist had misused a much-coveted invitation to the event. By questioning the event and its rules the columnist inadvertently also questioned the distantly participating viewers - a sore spot since the private Nobel Banquets can be seen as a form of "status-sponging" that undermines the sense of equality and participation in the occasion that the viewers strive for (ULMA 39316).

\section{INTERNATIONAL COUNTERPARTS}

Making an international comparison one will find that other countries have prizes similar to the Nobel Prize. In the United States there is the Laskar Prize for advances made in the field of medicine, in Japan there is the Kyoto Prize for advances in the fields of technology, basic sciences, arts and philosophy, and in Russia the recently established Global Energy Prize is beginning to establish reputability. Closer to home, in Norway, there is of course the Nobel Peace Prize Award Ceremony, including the Peace Prize Concert, but even in Norway counterparts to the privately arranged Nobel Prize Banquets are scarce. There are Nobel Banquets staged at the Nobel Institute in Oslo, by a firm called Meeting Professionals International, but this is a commercial enterprise and not a widespread custom (ULMA 39322: 6). ${ }^{10}$

Also in the United States, a somewhat surprising parallel is to be found in the glamorous Academy Awards. ${ }^{11}$ Some may resent this comparison between 
the prestigious Nobel Prize Awards and the more commercial Academy Awards, but nevertheless the Nobel Prize and the Academy Awards share some defining characteristics. The Nobel Prize Award Ceremony and the Academy Award Ceremony are both televised, and not only in their own countries but all over the world. The two events can also be defined as entertainment, as world-renowned entertainers are hired to perform for the attending guests and TV-viewers. Furthermore, the guests include the glamorous, rich, and famous celebrities that the TV audiences are interested in; the Nobel festivities involve the Swedish Royal family and the occasional celebrity or well-known politician, and the Academy Awards involve movie stars - often referred to as the American equivalence of royalty.

The annual broadcasts from the Nobel Prize Award Ceremony and the Nobel Banquet are one of the most important occasions of the year when it comes to the Royal family's exposure; the same is true of the Academy Awards and the movie stars walking down the red carpet. At both events a lot of attention is therefore made to detail, thus adding to the glamour of the occasion.

Interviewing these famous persons and investigating the clothes and jewellery they wear and the hairdos they show off, the television cameras take the viewers closer to royalty and the stars, than even the invited guests attending these events. This intimacy makes both royalty and movie stars seem more personable, thus also making them easier to identify with and to mimic.

\section{THE PRIVATELY ARRANGED ACADEMY AWARD PARTIES}

Swedes stage their own Nobel Prize banquets, and Americans throw private Oscar bashes - from casual get-togethers, where they watch television, criticise the stars, and predict the Oscar winners, to professionally organised parties where they dress up as fabulous or favourite movie stars (ULMA 39322: 6).

If you want to organise your own party, Fox News homepage gives tips on what to eat and the Washington Post tells online what the best party themes are - ideas inspired by the nominated movies. ABC's homepage advises what to eat and how to pick the winners. Tips are also given at oprah.com, the HGTV homepage and the about.com site.

Not only is there humorous chatter about the Nobel Banquet, but also about the Academy Awards, and not just made by the TV host. On LA Weekly's blog the lost invitation joke is expressed by lifestyle editor Linda Immediato (2006): "I wasn't invited to the Oscars, an oversight on somebody's part I'm sure."

Like the privately arranged Nobel Prize Awards, the guests at the more elaborate private Academy Award parties may take home a prize of their own - 
in the form of a gilded plastic Oscar or one made out of gold wrapped chocolate (ULMA 39322: 6). Again it is mainly women who organise the parties, and the Oscar ceremonies are even referred to as the "Super Bowl for women" (http:// www.cbsnews.com).

While researching the alternative parties, I found a second degree of the distanced participation: Jen Chaney (2006), movie editor at the Washington Post, organises web-parties where a group of people who do not know each other get together online to discuss the show they are all viewing... collectively, but not together. The "guests" were asked to "bring the wine, cheese and snarky comments":

Welcome to our Web version of an Oscar party. This is my third year hosting one of these discussions and, thanks to the wonders of technology, I'm typing from my couch this time, watching the red carpet action on my high-definition TV. So it's almost as good as being at the Kodak Theatre, plus I don't have to wear a gown and uncomfortable shoes. (http://www. washingtonpost.com)

Besides the American Academy Awards there is also another European parallel to be found in the UK, where there take place Eurovision Song Contest parties and people dress up in front of the television set during the final contest. ${ }^{12}$ The same thing happens in Iceland, sometimes with people singing along, similar to karaoke. ${ }^{13}$

\section{CONCLUSION}

The privately arranged Nobel Prize Banquets constitute a developing annual festivity in Sweden, involving banter and role play, and with parallels to both historic customs and current day international events. The alternative Nobel Prize Award Banquets are arranged in private homes, by various organisations, at kindergartens, schools, colleges and universities, by the more exclusive caterers, restaurants, inns and hotels, and by business event organisers, etc.

Maybe the increase in privately arranged Nobel Banquets is connected with the rising popularity of the Swedish monarchy and a surge for the exclusive expressed, for example, in the turn from sex to luxury in commercial advertising in Sweden. But on a deeper level the distanced participation of the national Swedish viewer can be seen as holding an important democratic aspect; for citizens to connect and identify with a national function and as an expression of national pride and a developing sense of nationality in an ever more inter- 
national society, where national identity and uniqueness can easily be felt to be fading.

An earlier version of this paper has previously been published in both Swedish an English: "Den alternativa nobelfesten. En tv-publiks festdeltagande", in Bodil lajv. Festskrift till Bodil Nildin-Wall den 18 januari 2007. Marlene Hugoson (ed.), Uppsala 2007, and under the English title in The Ritual Year and Ritual Diversity. Proceedings of the Second International Conference of the SIEF Working Group on the Ritual Year, Gothenburg June 7-11 2006. Lina Midholm, Annika Nordström and Maria Teresa agozzino (eds.), Göteborg 2007. In addition you can read Professor Christina Fjellström's (2006) article “Vad är väl en bal på slottet...' Nobelfest i slott och koja” ['What's a Royal Ball...' Nobel Banquets in Castle and Cabin] in $\mathrm{Nu}$ gör vi jul igen.

\section{ARCHIVAL SOURCES}

ULMA: The Uppsala Archive of Dialectology (Uppsala landsmålsarkiv), Sweden. This was formerly a separate archive, but is now incorporated with the Institute for Language and Folklore in Uppsala (Institutet för språk och folkminnen, Uppsala).

\section{NOTES}

1 I thank Kersti Wikström, curator at the Nordic Museum in Stockholm, for the parenthetical information.

2 The abbreviation SIEF stands for Société Internationale d'Ethologie et de Folklore. The Ritual Year is one of SIEF's working groups.

3 The study on the privately arranged Nobel Banquets is part of the project Förändring av sedvänjor (Changing Customs), a documentation of current Swedish customs and the extensive changes they are undergoing, initiated in 2003 by the Folklore Department at the former Institute for Dialectology, Onomastics and Folklore Research, in Uppsala. Now reorganised and named the Swedish Institute for Language and Folklore. The project has focused on the more constant among Swedish folk customs - such as annual festivals and celebrations and life cycle celebrations.

${ }^{4}$ When Alfred Nobel drew up his will - stipulating, among other things, that the Nobel Peace Prize Award Ceremony was to be held in Norway and not Sweden - the two countries were still a union. When the union came to an end in 1905 this arrangement continued. For more information, see http://nobelprize.org/ and http://www.nobel.no/.

5 See, e.g., Pawel Flato's and Niklas Lindblad's (2000) Nobelfesten and Hélène Bodin's (1998) Nobelfesten. Moderna recept från klassiska menyer. 
6 The idolisation and mimicking of royals can be found around Queen Elizabeth II of the United Kingdom, and whenever there is a grand royal wedding.

7 I thank Laura Aronovici, supervisor at the Nobel Museum Shop in Stockholm for the information about the chocolate.

8 Over a long period of time Publik spisning (Dining in public) could be found in courts around Europe, for example in the court of Swedish queen Christina in the 17th century, and Swedish king Gustavius III in the 18th century (Strong 2002: 134, 202-258).

9 The term Jantelagen was coined in 1933 by Norwegian-Danish author Aksel Sandemose in his book En flykting korsar sitt spår [A Refugee Crosses His Tracks], in which he listed the ten commandments of Jante.

${ }^{10}$ I thank Professor Anders Gustavsson and Professor Arne Bugge-Amundsen, at the Department of Culture Studies and Oriental Languages (IKOS) at the University of Oslo, Norway, for the (negative) information.

11 The Emmy, Grammy, Golden Globes, or Tony Awards could also have been used as a comparison, as there are private parties of the same kind in connection with them. However, these prize awards are not as old, nor as widely known as the Academy Awards, making them less of an example in the comparison (ULMA 39322:6).

${ }^{12}$ I thank Kate Smith, a doctoral student at the University of Sheffield, England, for the information.

${ }^{13}$ I thank Terry Gunnell, Associate Professor in Folkloristics at the University of Iceland, for the information.

\section{REFERENCES}

Bodin, Hélène (ed.) 1998. Nobelfesten. Moderna recept från klassiska menyer. [The Nobel Banquet. Modern Recipies from Classical Menus.] Stockholm: Mixoft.

Chaney, Jen 2006. Oscar Night Party. Live Coverage of the 78th Academy Awards. (Published on 5 March 2006, collected on 24 July 2006), not found in the webpage's search engine, instead see Google (www.google.com), search words "oscar night party" and "live coverage of the 78th academy awards". http://business. highbeam.com/437235/article-1G1-142855183/oscar-night-party-live-coverage78th-academy-awards, last accessed on 15 March 2012.

Fjellström, Christina 2006. 'Vad är väl en bal på slottet...' Nobelfest i slott och koja. ['What's a Royal Ball...' Nobel Banquets in Castle and Cabin.] In: C. Hagström \& M. Hugoson \& A. Nordström (eds.) Nu gör vi jul igen. [Re-creating Christmas Again.] Gothenburg: Institutet för språk och folkminnen, University of Gothenburg.

Flato, Pawel \& Lindblad, Niklas 2000. Nobelfesten. [The Nobel Banquet.] Stockholm: Prisma. 
Forsström, Maria 2005. Budgetfira kungligt hemma: Metro tipsar: Rätt kläder, hår och mat för Nobelfesten. [Royal Low-Cost Celebration at Home. Metro Gives Tips on the Right Clothes, Hair, and Food for the Nobel Banquet.] Metro, December 9.

http://www.cbsnews.com/. Throw a Last-Minute Oscars Bash! (Published on 26 February 2005, collected on 15 September 2006), search words = throw a last-minute oscar bash, last accessed 15 March 2012.

http://www.ur.se/television. 1950-talet. [The 1950s.] (Collected 24 July 2006), menu choice $=$ TV-historia/1950-talet, last accessed 15 March 2012.

Hugoson, Marlene 2007. Den alternative nobelfesten. En tv-publiks festdeltagande. [The Popular Nobel Prize Award Banquet. The Distanced Participation of an Interacting TV-Audience.] In: M. Hugoson (ed.) Bodil lajv. Festskrift till Bodil Nildin-Wall den 18 januari 2007. Uppsala: University of Uppsala.

Immediato, Linda 2006. The Problem With Oscar. (Published on 6 March 2006, collected on 18 July 2006). http://blogs.laweekly.com/arts/2006/03/index.php?page=4, last accessed on 15 March 2012.

Karlsson, Mia 2004. Tittarstorm mot Linda Skugge. [Viewers Storm Against Linda Skugge.] Expressen December 11. http://www.expressen.se/nyheter/tittarstormmot-linda-skugge/, last accessed on 15 March 2012.

Kinberg, Linda 1999. Festlig nobelbal för ett fåtal. [Festive Nobel Ball for Select Few.] Vertex. Norrlands största studenttidning [Vertex. The District of Norrland's Largest Student Paper], No. 9.

Skugge, Linda 2004a. Linda sätter betyg på festen alla talar om. [Linda Grades the Feast Everyone is Talking About.] Expressen, December 11. http://www.expressen.se/nyheter/linda-satter-betyg-pa-festen-alla-talar-om/, last accessed on 15 March 2012.

Skugge, Linda 2004b. Sluta hata mig så mycket, tänk på era hjärtan. [Stop Hating Me So, Consider Your Hearts.] Expressen, December 25. http://www.expressen. se/kronikorer/linda-skugge-sluta-hata-mig-sa-mycket-tank-pa-era-hjartan/, last accessed on 15 March 2012.

Strong, Roy 2002. Feast. A History of Grand Eating. London: Jonathan Cape.

SVT production 2004. DVD, Guldkorn från 1948-1950. Åren var 1948-1950. [Olden Goldies from 1948-1959. The Year Was 1948-1950.] SVT produktion 2004. [A Production from Swedish Television 2004].

SVT 2004. Televised broadcasting, SVT [Swedish Television], December 10. Nobelfesten [The Nobel Banquet].

SVT 2005. Televised broadcasting, SVT [Swedish Television], December 10. Nobelfesten [The Nobel Banquet]. 


\section{Internet sources}

Google search engine for "Nobel", "Nobelfest" [Nobel Banquet], "Nobelmiddag" [Nobel Dinner], "Nobellunch" [Nobel Lunch], "Fredspriskonsert" [Peace Prize Concert], "Nobel Peace Prize Award Ceremony", "Peace Prize Concert", "Academy Awards", "Oscars", "Oscar bash", Oscar party", "Emmys", "Tonys", "Golden Globes”. The research material collected is too extensive to be presented as a whole, but can be found in the Research Archive of the Institute for Language and Folklore, in Uppsala, Sweden (ULMA accession number 39322, see archival sources above). 